\title{
DIFFERENT AGE GROUPS' RESPONSE TO EMPLOYMENT EQUITY PRACTICES
}

\author{
ASHLEY WALBRUGH \\ GERT ROODT \\ Department of Human Resource Management \\ Rand Afrikaans University
}

\begin{abstract}
The focus of this article is on response differences with regard to employment equity practices within nine South African companies from different industries, as well as whether the Employment Equity Questionnaire is a reliable tool for measuring employment equity practices. A convenience sample of 4729 participants in the field survey provided the secondary data for this study. The Employment Equity Questionnaire yielded a high Alpha coefficient of 0,96 . The main findings were that differences in responses between age categories do exist, but only a small percentage of the variance could be ascribed to differences in employment equity practices. In addition to this, the South African companies show the same trends, with regard to age discrimination, as other countries like the United States and Britain. This finding could therefore serve as a lead indicator for proactive measures - to ensure that the same mistakes from other countries are not repeated here.
\end{abstract}

\section{OPSOMMING}

Die fokus van hierdie artikel is op responsverskille met betrekking tot gelyke werkgeleentheidpraktyke binne nege Suid-Afrikaanse maatskappye in verskeie industrieë en ook of die Employment Equity Questionnaire 'n betroubare instrument is om gelyke werkgeleentheidpraktyke te meet. 'n Geleentheidsteekproef van 4729 deelnemers in die veldopname het die sekondêre data vir hierdie studie voorsien. Die Employment Equity Questionnaire het 'n hoë Alfakoëffisiënt van 0,96 opgelewer. Die hoofbevindinge is dat daar verskille in response tussen ouderdomsgroepe bestaan, maar dat slegs 'n klein proporsie van die variansie aan verskille in gelyke werkgeleenthede toegeskryf kan word. In aansluiting hiermee, wys Suid-Afrikaanse maatkappye dieselfde tendens met betrekking tot ouderdomsdiskriminasie as ander lande soos die VSA en Brittanje. Hierdie bevinding moet as 'n kernaanwyser vir proaktiewe maatstawwe beskou word - sodat dieselfde foute van ander lande nie hier herhaal word nie.

Clarifying concepts in the employment equity context Since the early 1960's one finds traces of federally sponsored equal employment laws that have been enacted prohibiting workplace discrimination based on age, colour, disability, national origin, race, religion and sexual orientation.

But what is meant by these terms that are so interchangeably used? Loden (1996, p.14), in her book on Implementing Diversity, defined diversity as "those important human characteristics that impact individuals' values, opportunities, and perceptions of self and others". In her definition of diversity in a workplace, she included primary dimensions such as age, ethnicity, gender, mental/physical abilities and characteristics, race and sexual orientation. Secondary dimensions of diversity include items such as communication style, education, family status, military experience, religion, first language, geographic location, income, work experience, work style and organisational role.

According to Noe, Hollenbeck, Gerhart and Wright (2000, p.77), Equal Employment Opportunity (EEO) referred to "the government's attempt to ensure that all individuals have an equal chance for employment, regardless of race, colour, religion, sex, or national origin".

While the equal employment opportunity legislation encouraged nondiscrimination, they offered no specific guidelines for correcting historic patterns of exclusion and discrimination. Affirmative action measures were designed to level the playing field.

The term 'affirmative action' has been used in various countries such as Malaysia, India, Sri-Lanka and the United States to describe various equity policies. One also needs to distinguish between affirmative action as a means of redressing inequality, and reverse discrimination, which preferentially advantages certain groups at the expense of others.

Requests for copies should be addressed to: A Walbrugh, Department of Human Resource Management, RAU University, PO Box 524, Auckland Park, 2006
Thomas (1992, p.3) argued that affirmative action "can be viewed as a pro-active development tool to overcome...constraints and more effectively mobilize latent resources in order to stimulate overall development". According to Thomas, various dimensions of affirmative action exist, and they include the political sphere and the decision-making process, education and culture, breakdown in segregation in social life, sport entertainment and recreation, housing and residential infrastructure, welfare services, black business advancement, job/employee advancement and training, symbolism and the historical perspective.

As can be seen from the above definitions, diversity management is a tool that can be used to achieve equal employment opportunity or employment equity (EE) depending on the perspective one wants to attach to it. From a business perspective it should therefore be addressed from a holistic view. It should form part of an integrated strategic business model addressed in its entirety.

Some international trends on employment equity and age Goldberg (2000), in her article on age discrimination, argued that the median age of employees in the United States has risen dramatically. She estimated that by the year 2030 there would be four times as many people over the age of 65 years as there were in 1960, and that the labour force participation of this age category will have to increase by $25 \%$ to maintain a constant total employment - to - population ratio from 2005 onward. This proves that there is definitely an increase in the number of older employees needed for employment in various categories.

Furthermore, Goldberg (2000) found that many Americans are leaving the workforce because they are downsized, displaced or disillusioned. She also stated that most people look forward to retirement because they are tired of stressful or unpleasant jobs and not because they are tired of working. The positive news, however, is that due to technological advances, many citizens are doing things they did not think were possible in the past 
Today's seniors are participating in athletic competitions, pursue college degrees, and continue to work full-time in a different profession or part-time in the same profession.

Despite this positive news, the American Association for Retired Persons - AARP (2002) has found that age discrimination still exist, and in some cases, more subtle than others. Discrimination includes refusing to hire or promote older workers, coercing them to retire, targeting them when a workforce reduction exercise is necessary and curtailing their benefits. Other forms of discrimination include limiting their training and development opportunities, job responsibilities and duties. Whether blatant or subtle, it is regarded as discrimination and is against the law.

Despite to the technological advances mentioned earlier, Woolnough (2000) found that older people find it hard to find and keep jobs in the Information Technology Industry. Woolnough (2000, p.2) still believed that the IT industry is ageist, especially where the belief still exist that to be successful in this sector, one needs to be 25 years old. Adding to this, she states that the assumption is still made that "older people can't and won't want to learn". This supports the AARP's view, and supports that, despite anti-discrimination legislation, discrimination against the aged still exist.

Recent movement in the US legislation has been interesting. Although legislation like the Age Discrimination Act of 1975 and the US Code specifically prohibit discrimination against the aged in any way, one still finds different opinions on this issue. A recent study by the US Code (sec 623, 1967) revealed that older workers find themselves disadvantaged in their efforts to retain employment, and especially to regain employment when displaced from jobs. In addition, the setting of arbitrary age limits regardless of potential for performance has become common practice. The study also revealed a high incidence of unemployment with a resultant deterioration of skills, morale, and employer acceptability. Even though the legislation prohibits unfair discrimination against the aged, one finds that, over time, discriminatory practices have become almost "best practice".

It was in this light that, based on a Supreme Court finding in 1989 in Public Retirement System of Ohio versus Betts, the Congress found legislative action necessary. This was to restore the original congressional intent in passing and amending the Age Discrimination in Employment Act of 1967 (29 U.S.C. 621 et seq.). The original intention was to prohibit the discrimination against older workers in all employee benefits, except when agebased reductions in employee benefit plans are justified by significant cost reductions.

Current amendments to this act is the doing away with statutory retirement at the age of 65 years, propagating that employees should be allowed to work beyond the retirement age, provided that they can still perform the duties required.

A London based organisation, Help The Aged, in its Policy Statement (2002, p.1) strongly spoke out against age discrimination. In this statement, they state that "Ageism and age discrimination exist routinely in British society and go to a large extent unnoticed and unchallenged".

Like the United States, Britain is following pretty much the same route with regards to the introduction of new legislation. According to Help The Aged (2002, p.1) the National Framework for Older People requires that age discrimination should be "rooted out". In addition to this, European law requires that the UK should ban age discrimination in employment by 2006 . The British Government is currently consulting on this issue. Recent moves in this regard is that the Government, by virtue of The Human Rights Act (Act 1998 Commencement No 2), wants to pursue the objectives of equality and diversity through a proposal to establish a Single Equality Commission to cover all forms of discrimination.
Research conducted by McGregor (2000) in New Zealand, revealed similar findings as in the USA and the UK. McGregor (2000) found that discrimination on the grounds of age was followed by discrimination in matters of promotion, and by discrimination within the workplace culture. She found that slightly more women than men reported discrimination $(13,6 \%$ as against 10,7\%). McGregor (2000) also found that age discrimination cases were significantly under-reported. The report speculates that this could be because workers are unaware that on-the-job discrimination can be grounds for complaint.

In summary therefore, even though various countries are geographically dispersed, the same occurrences exist with regard to age discrimination. It appears that everywhere Governments are waking up to the call from the aged to continue to work as long as they can add value. The article will now focus on age patterns in Employment Equity in a South African context.

A South-African perspective on employment equity and age In the context of black advancement, affirmative action can be traced back to the middle seventies. According to Deloitte \& Touche (2001) the 1976 riots led to the fact that companies, especially multinationals were placed under pressure from their origins either to divest from South Africa, or to embark on intensive black advancement programmes. This pressure would subsequently evolve into the Sullivan Code in 1977, which eventually lost its impact after the then president P W Botha's Rubicon speech in the late eighties.

The Wiehahn Commission was instrumental in legislating trade unions. Their rapid growth, the formation of the UDF, the imposition of a state of emergency, and the formation of Comprehensive Anti-Apartheid Act of 1986 led to affirmative action once again gaining impetus, only soon to lose it again as expectations were being met.

In February 1992 came the unbanning of political organisations and the release of political prisoners, resulting in again intense affirmative action initiatives. In 1993 South Africa was in transition from an apartheid system, to a non-racial, non-sexist democracy and because of the imbalances caused by apartheid, there was much talk of affirmative action, but no policy or guidelines existed.

The release of the White Paper on Reconstruction and Development (Notice No. 1954 of 1994) highlighted the need for business to bring forward viable options. The PAC and AZAPO also had affirmative action proposals in their economic policy position. The pressure to implement affirmative action grew, and it was felt that if major business failed to come up with proposals, then a future democratic government would have to impose affirmative action policy and guidelines.

The framework for non-discriminatory legislation was captured in the Constitution of the new South Africa. According to Chapter Two in the Constitution (1996) under Bill of Rights section 7(1) it states that the Bill is "the cornerstone of democracy, and it affirms the democratic values of dignity, equality and freedom". On equality section 9(3) clearly states that "the state may not unfairly discriminate directly or indirectly against anyone on one or more grounds, including race, gender, sex, pregnancy, marital status, ethnic or social origin, colour, sexual orientation, age, disability, religion, conscience, belief, culture, language and birth" (own emphasis).

The Labour Relations Act (Act 66 of 1995), the forerunner of the Employment Equity Act (Act 55 of 1998), set the wheels in motion for employment equity. The Labour Relations Act (Act 66 of 1995) states in Chapter 8, section 187(f) that "any employer who amongst others dismiss an employee based on amongst others age, is guilty of an automatic unfair dismissal" (own emphasis). The Employment Equity Act states in Chapter 2 section 6(1) that "no person may unfairly discriminate, directly or indirectly, against 
an employee in an employment policy or practice on grounds including age" (own emphasis). The main aim of this Act was the removal of all obstacles to equality of opportunity (including age) and the implementation of affirmative action measures.

As part of the enforcement of the Employment Equity Act (Act 55 of 1998), the Department of Labour required companies to report on progress made towards achieving set goals. The first reports were submitted in October 2000. Apart from systems problems experienced by the department, the results were devastating. The Department of Labour (2000) released a report that stated that no significant improvement in the representation of designated employees since the baseline profiles of 1998.

Interestingly, the report does not reflect on age barriers to employment equity in any of its forms or reporting structures. This is quite contradictory, given the fact that age discrimination is quite prominent in the SA constitution, as well as in the Employment Equity Act and in the Labour Relations Act. Comparatively speaking, it appears that South Africa is pretty much going down the same route as international predecessors in this field, and might also find government enforcing the intent of legislation quite soon.

The current HIV/AIDS pandemic in South Africa might force decision-makers to critically review the position on employing the aged and will be discussed broader in the section that deals with age as an element of employment equity.

In the next section, more focus will be given to one dimension of equity, namely age.

\section{Age as an element of employment equity}

Schein's (1978) typology of three career stages is widely reported in the literature. The early career stage is associated with career establishment, development of work values and career anchors. During this stage young adults seek opportunities for advancement, social status and recognition. The main tasks in the early career stage revolve around career establishment and career achievement (Schreuder \& Theron, 2001). It is therefore expected that career entrants will be able to deal with challenges of employment equity in a creative way.

During the mid-career stage adults are grappling with issues around redefining one's identity, clarifying one's values and philosophy of life and adjusting to changes in family life. It is also during this stage that the mid-life crisis can occur (Gerdes, Moore, Ochse \& Van Ede, 1988). Individuals are dealing with existence related issues in life such as "what have I achieved?" or "where am I going?" Remaining productive during this stage can be hampered with issues such as job-loss, obsolescence and discrimination (Schreuder \& Theron, 2001). It can therefore be expected that adults in the mid-career stage will respond more negatively to EE practices.

During the late career stage individuals are dealing with declining physical and mental abilities, due to general ageing or poor health. According to Robbins (2001), worldwide, the importance of age is increasing mainly due to three reasons. Firstly, there is a widespread belief that job performance deteriorates with an increase in age. Regardless whether it is true or not, a lot of people believe it and act on it. Secondly, there is the reality that the workforce is aging. Workers in the 55 and older category are the fastest growing sector of the labour force. The third reason, for all intents and purposes in the US, mandatory retirement has been outlawed, thus meaning that no US workers have to retire at the age of 70 years.

The perceptions, Robbins (2001) further stated, of older workers, are mixed. Some hold various positive qualities like experience, judgment, a strong work ethic, and commitment to quality. In contrast older workers are also seen as less flexible and being resistant to new technology. This negatively affects the hiring of older workers in times when companies go through change and are seeking younger flexible employees. What effect does age really have on turnover, absenteeism, productivity and satisfaction?

McEvoy and Cascio (1989) have shown that the older you get, the less likely you are going to quit your job. As employees get older, they have fewer opportunities, and in many cases become less ambiguous. Their studies have also shown that the elderly are less likely to resign as they are seeking benefits such as longer paid leave, medical aid, and better pension benefits.

Another perception to be dealt with is that age is positively related to absenteeism. One can argue that if they are less likely to quit, then they will be more willing to come to work more regularly. Studies have actually shown that there is a positive relationship between age and absenteeism, but it is partially a function of whether the absence is avoidable or unavoidable. In general, older employees have lower rates of avoidable absenteeism than younger employees, but show higher rates of unavoidable absenteeism. This can mainly be due to the general poorer health that comes with aging as well as the longer recovery period when injured (McEvoy \& Cascio, 1989).

McEvoy and Cascio (1989) reported in the same study there is also a widespread belief that productivity declines with aging, and the assumption is made that the person's speed, agility, strength and coordination decay over time. This might cause boredom and lack of intellectual stimulation. The evidence, however, contradicts these beliefs. Studies conducted in hardware stores that staffed the store with over 50 's have proven to be more productive than "younger" stores. These studies have also shown that age and job performance is unrelated. This finding seems to be true for both professional and nonprofessional jobs. The conclusion was that the natural requirements of the job are not extreme enough for any decline in physical skills due to age, to have an impact on productivity.

The last concern to deal with, focuses on the relation between age and satisfaction. Here, the evidence is mixed. Most studies show a positive association between age and satisfaction, at least up to 60 years. Other studies, however, have found a U-shaped curve. McEvoy and Cascio (1989) found that with professionals, satisfaction tends to continuously increase, whereas it falls with non-professionals.

In the South-African context, as in many other parts of the world, there is also another influence to consider and that is the impact of the HIV/AIDS pandemic. The US Census Bureau (2002) projected South Africa's population pyramid in different age categories up to the year 2050 .

According to this projection by the US Census Bureau (2002), there will be a dramatic decrease in the younger population categories, especially in the economic active population, as well as the infant and younger age categories. Conversely, the older age categories showed a steady increase. Assuming that these projections are correct, it will mean that companies might be forced to revert to "older" employees to source employment from. There simply will not be enough younger people to employ. This will also mean that legislators might have to revisit statutory retirement age legislation. South Africa might soon find itself in the situation, where companies cannot afford to let older employees go on retirement. If allowed to do so, while there is no steady inflow of skills into the company, they might find themselves in a "skills drain" situation.

Given these projections, as well as what is happening in the rest of the world, that it is quite clear that employment equity is becoming more of a strategic issue than what most want to give it credit. It is therefore crucial that one understands employment equity in totality, but also the different domains underpinning it. 

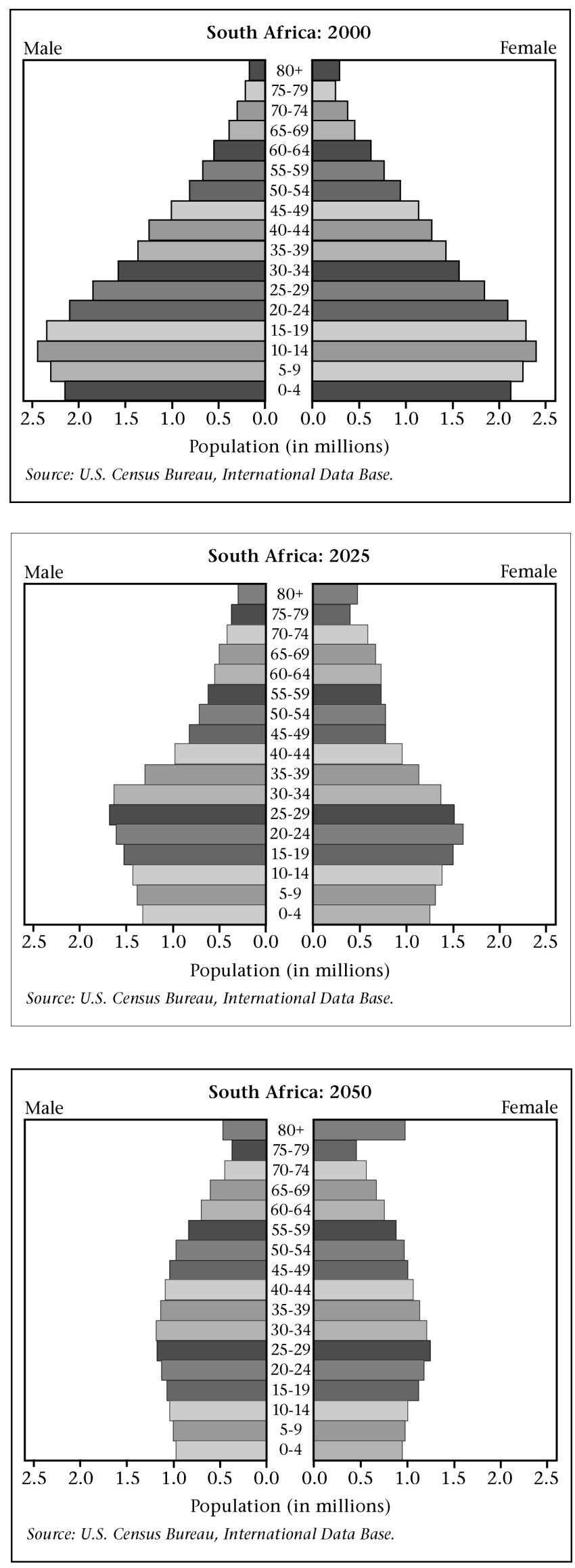

Figure 1: Projected population growth for South Africa

The next section deals with a conceptual framework for an employment equity strategy, specifically focusing on the different domains making up the conceptual model.
Conceptual framework for an employment equity

(EE) strategy

Human (2001) argued that many organisations have simply "tacked" initiatives such as management of diversity and employment equity onto a human resources function which, in many cases, is not supporting the main business agenda of the organisation. According to Human, the challenge for companies is:

- to align the HR strategy with the business strategy of the company, to create an integrated HR Strategy that incorporates employment equity, skills development, and labour relations.

- to clearly define the roles and responsibilities with respect to these issues and performance management and monitoring processes relating thereto.

- to put in place practical processes while responsibilities need to be assigned at departmental level, for only this way can real progress be achieved.

\section{Components of an Integrated Employment Equity}

\section{Framework/Strategy}

Given the points made above, business strategy of any organisation pre-determines the broader HR Strategy, and hence, what is possible in terms of employment equity and education and training.

Human's (2000) experience in other companies and countries suggest that employment equity initiatives and human resources strategies need to be integrated for optimal results. Adding to this, as many of the activities take place in a line function, line management also has to be held accountable for them. In many cases this responsibility is relegated to HR or transformation sections, and this practice is unsound. These service departments provide line with advice and should be competent to do so. They also play a key role in the setting of policies, procedures, integration, monitoring and evaluation. The following is a schematic diagram of the Human (2000) model.

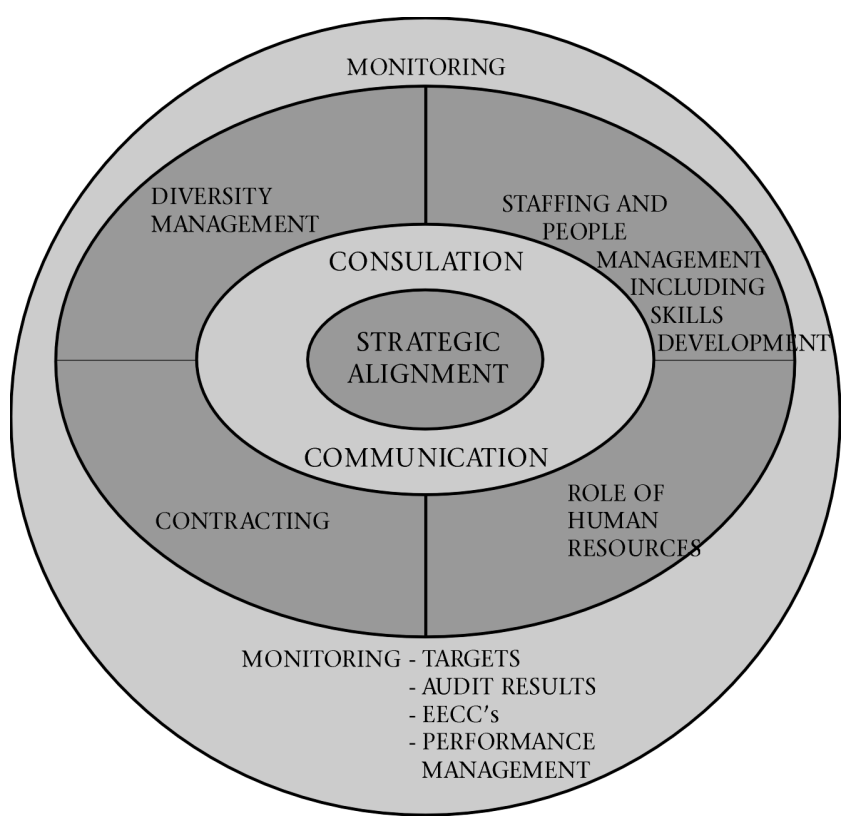

Figure 2: A conceptual framework for an integrated employment equity strategy

The following are critical success factors/domains that are regarded as pre-requisites for effective and integrated $\mathrm{EE}$, training and education/human resources strategy.

\section{Strategic Alignment}

Where possible, EE should be identified as a key strategic issue and is managed in the same way as other strategic goals. The CEO also understands EE and its potential advantages and is 
committed to its implementation and monitoring. For EE to be successful, it is crucial that all levels understand and is committed and understands its relevance to the organisation. Line managers should have specific measurable EE objectives as part of their performance contracts. Likewise, nonperformance should have sanction of rewards. Employees through out the organisation are regularly consulted about EE; communication on the EE strategy is effective and there is a clear understanding of the strategy and roles and responsibilities of all role players.

\section{Staffing and People Management}

In this domain, workforce, succession and individual career plans should be in place while numerical goals (race, gender, age, disability targets) are set and stringently monitored. Reasonable accommodation is made to accommodate people with disabilities and recruitment, selection and promotion policies are fair. The fallacy that EE equals the lowering of standards should be countered through motivation and productivity improvement measures. Managers should also have the commitment and skills to develop their subordinates and become competent in managing diversity. Employees on the other hand must have clear job objectives and performance standards, and receive honest feedback on a frequent basis.

\section{Managing Diversity}

A basis for an effective people management culture is a belief in the basic equality and dignity of all people, as people, irrespective of position, race, gender, physical and mental ability, wealth, sexual orientation and age. Some schools of thought believe that age can be used to discriminate fairly.

The above understanding should be underpinned by a respect for individuals and understand the negative effects of stereotyping. There should also be the belief that all people, provided that they are managed and developed correctly, have a great deal to offer the company. Such beliefs would inevitable lead to people being matched to jobs based on required criteria, rather than stereotypes.

In addition, there should be an understanding of how people express their different cultural and religious beliefs, and these should be accommodated as far as possible. These differences in ethnic culture, eating habits, dress, religion, levels of physical ability, etc. would be seen as enriching. The varied backgrounds (not varied in performance) create the context in which new customers, suppliers and other stakeholders can be discovered.

Human (2000) also found that where managers steer away from stereotyping towards assessing of people on job-related criteria, genuine employment equity could take place. These managers begin to take personal responsibility for effective interaction with employees and create a dignified and respectful environment where employees are treated as individuals. They further provide positive, constructive feedback based on job performance rather than "writing people off". These managers also identify training needs in consultation with employees and they are based on development needs. Agreed career plans are based on strengths and development areas and they are used to motivate and retain individuals. Such managers interact socially with all groups, while designated group members have the same responsibilities and accountabilities as white colleagues. Policies and procedures do not discriminate against designated employees while the same benefits apply to all employees.

\section{Commercial Equity/Contracting}

The objective with commercial equity/contracting is to contribute to the development of a stable socio-economic environment by supporting the growth and development of
SMME's (Small Medium and Micro Enterprises). These entrepreneurs from designated backgrounds are placed in long lasting, profitable and sustainable commercial relationships with the company. The organisation also assists with the development of female and black-owned business and where possible, the product/services needed are purchased from black empowered businesses.

\section{Role of Human Resources in Employment Equity}

The Human Resources department normally has a high level of credibility and is actively and positively committed to EE issues. They also play a key role in the development of policies, procedures, co-ordination, integration, support, monitoring and evaluation of EE initiatives.

\section{Purpose of this study}

As noted earlier in this article, all indications are that with regard to employment equity, and more specifically age discrimination, South Africa should avoid moving in the same direction as other overseas countries.

The primary aim of this study was to determine whether response differences among different age categories exist on employment equity practices of respondents from different companies.

The secondary objective of the study was to determine the internal consistency of the Employment Equity Questionnaire that was used.

\section{METHOD}

\section{Methodological design}

The methodological design followed in this study can be broadly categorized as empirical and quantitative in nature. The data for the current study can be typed as secondary because it was obtained from the developers of the Employment Equity Questionnaire and not generated by the researchers themselves. The approach followed in the study can be described as retrospective or ex post facto research.

\section{Participants}

A total of nine South African companies completed the Employment Equity Questionnaire, and they included employees (\% in parentheses) from companies from the electronic media $(32,8 \%)$, banking $(41,6 \%)$, vehicle manufacturing $(3,5 \%)$, retail $(1,5 \%)$, chemical $(1,1 \%)$, information technology $(16,6 \%)$ and tertiary education $(2,8 \%)$ sectors.

In reference to Table 1 , a total of 4729 respondents participated, constituting the sample of convenience. With regards to the age categories, the sample was divided into seven categories. The 24 years and younger category constituted $14,1 \%$, the 25 to 30 years category $19,0 \%$, the 31 to 35 years category $13,7 \%$, the 36 to 40 years category $14,4 \%$, the 41 to 45 years category $15,3 \%$. The 46 to 50 years category $10.9 \%$, and the 51 years and older category constituted $11,5 \%$ of the sample. A total of 84 responses was missing and constituted $1,1 \%$ of the sample.

In terms of racial distribution, the sample was well represented. A total of $23,3 \%$ was Black, $7,2 \%$ were Coloured, $2,6 \%$ were Indian/Asian and $36,2 \%$ were White. A total of $30,7 \%$ did not respond on this category.

All South Africa's official language groups were represented in the sample. Afrikaans was the most predominant language group with 51,8\% representation, while English had 20,2\% representation. Other languages represented were Ndebele $(0,9 \%)$, Northern Sotho $(4,1 \%)$, Southern Sotho $(2,3 \%)$, Swazi $(0,7 \%)$, Tsonga $(2,4 \%)$, Tswana $(9,2 \%)$, Venda $(0,7 \%)$, Zulu $(3,8 \%)$, and other languages represented $0,6 \%$ of the population. A total of $3,2 \%$ responses were missing from the sample. 
TABbLe 1

BIOGRAPHICAL DATA OF THE SAMPLE

\begin{tabular}{|c|c|c|c|}
\hline & & Frequency & $\%$ \\
\hline \multicolumn{4}{|c|}{ COMPANY DISTRIBUTION } \\
\hline \multirow[t]{10}{*}{ Valid } & ELECTRONIC MEDIA & 1549 & 32,8 \\
\hline & BANKING & 1055 & 22,3 \\
\hline & BANKING & 914 & 19,3 \\
\hline & VEHICLE MANUFACTURING & 166 & 3,5 \\
\hline & RETAIL & 70 & 1,5 \\
\hline & CHEMICAL & 52 & 1,1 \\
\hline & INFORMATION TECHNOLOGY & 526 & 11,1 \\
\hline & EDUCATION & 138 & 2,8 \\
\hline & INFORMATION TECHNOLOGY & 258 & 5,5 \\
\hline & Total & 4728 & \\
\hline \multicolumn{2}{|c|}{ Missing System } & 1 & \\
\hline \multicolumn{2}{|l|}{ Total } & 4729 & 100 \\
\hline \multicolumn{4}{|c|}{ AGE DISTRIBUTION } \\
\hline \multirow[t]{8}{*}{ Valid } & 24 years and younger & 665 & 14,1 \\
\hline & 25 to 30 years & 699 & 19,0 \\
\hline & 31 to 35 years & 649 & 13,7 \\
\hline & 36 to 40 years & 680 & 14,4 \\
\hline & 41 to 45 years & 724 & 15,3 \\
\hline & 46 to 50 years & 614 & 10,9 \\
\hline & 51 years and older & 644 & 11,5 \\
\hline & Total & 4675 & 98,9 \\
\hline \multicolumn{2}{|c|}{ Missing System } & 84 & 1,1 \\
\hline \multicolumn{2}{|l|}{ Total } & 4729 & 100 \\
\hline \multicolumn{4}{|c|}{ RACE DISTRIBUTION } \\
\hline \multirow[t]{5}{*}{ Valid } & Black & 1100 & 23,3 \\
\hline & Coloured & 341 & 7,2 \\
\hline & Indian/Asian & 125 & 2,6 \\
\hline & White & 1713 & 36,2 \\
\hline & Total & 3279 & 69,3 \\
\hline \multicolumn{2}{|c|}{ Missing System } & 1450 & 30,7 \\
\hline \multicolumn{2}{|l|}{ Total } & 4729 & 100 \\
\hline \multicolumn{4}{|c|}{ LANGUAGE DISTRIBUTION } \\
\hline \multirow[t]{12}{*}{ Valid } & Afrikaans & 2451 & 51,8 \\
\hline & English & 957 & 20,2 \\
\hline & Ndebele & 41 & 0,9 \\
\hline & North Sotho & 195 & 4,1 \\
\hline & South Sotho & 110 & 2,3 \\
\hline & Swezi & 33 & 0,7 \\
\hline & Tsongo & 115 & 2,4 \\
\hline & Tswana & 435 & 9,2 \\
\hline & Venda & 32 & 0,7 \\
\hline & Zulu & 161 & 3,8 \\
\hline & Other & 30 & 0,6 \\
\hline & Total & 4580 & 96,8 \\
\hline \multicolumn{2}{|c|}{ Missing System } & 149 & 3,2 \\
\hline \multicolumn{2}{|l|}{ Total } & 4729 & 100 \\
\hline \multicolumn{4}{|c|}{ GENDER DISTRIBUTION } \\
\hline \multirow[t]{3}{*}{ Valid } & Male & 2296 & 48.5 \\
\hline & Female & 2349 & 49.7 \\
\hline & Total & 4645 & 98.2 \\
\hline \multicolumn{2}{|c|}{ Missing System } & 84 & 1.8 \\
\hline \multicolumn{2}{|l|}{ Total } & 4729 & 100 \\
\hline
\end{tabular}

With regards to gender distribution, $48,5 \%$ were male, while $49,7 \%$ were female. A total of $1,8 \%$ of the responses were missing.

\section{Measuring instrument}

Martins (1999) developed the Employment Equity Questionnaire. It consisted of 146 questions and is divided into 4 sections/domains. Section 1,2 and 3 required information on the Employment Equity process. Section 4 consists of a couple of questions on biographical information, such as age and qualifications.

Compared to the conceptual framework (Figure 1), sections 1, 2 and 3 deal with diversity management, monitoring and communication, contracting, staffing and people management, skills development, role of Human Resources, targets, audit processes, and performance management. Only 41 items common to all nine companies participating in the survey were used in the current study.

Participants were asked to mark their responses to the questions with a cross $(\mathrm{X})$ on a rating scale. The scale consisted of four categories, and they are:

$1=$ Strongly Disagree

$2=$ Disagree

$3=$ Agree

$4=$ Strongly Agree

The respondents' ratings were determined by the measure they either agreed or disagreed with the statement made in each question. In addition, they were asked to mark all the questions and only to choose one answer per question.

The following are some examples of the sample items used in the Employment Equity questionnaire (1999):

Item 33. I think in (name of company) recruitment takes place without unfair discrimination in terms of race, gender, religion, disability, age, etc.

Item 38. An effort is made by management to convey information to me in such a way that I understand it.

Item 94. In my department employees are encouraged to use/develop their own skills/abilities and to improve them further.

\section{Procedure}

Martins (1999) approached the participating companies to conduct the survey in participation with a company called Organisational Diagnostics (1999). The participants inside the companies were selected on a voluntary basis. Participants were briefed by a facilitator and asked to complete the questionnaire. Participants were assured that the information was going to be treated as confidential, and that the questionnaire was going to be filled in anonymously. Participants were also assisted by facilitators when questions had to be translated into their own languages.

They were asked to complete the hard copy questionnaire as honestly as possible and each question had reference to the Employment Equity process. The data collected by Martins was put in secondary format to the avail of the researchers for the purposes of this study.

\section{RESULTS}

The statistical analysis of the data was conducted in two phases, i.e. a factor analytical phase and an inferential statistical analysis phase. The following is a more detailed description of the analyses that were conducted.

\section{First phase of the data analysis}

The factor analyses were conducted on two levels. In the first level analysis, the 41 items of the questionnaire were intercorrelated. The suitability of the inter-correlation matrix for factor analysis was tested by means of a Kaiser-Meyer-Olkin (KMO) measure of sampling adequacy and the Bartlett's Test for sphericity. These results are presented in Table 2 . The obtained values indicate that the matrix is suitable for factor analysis. 
TABLE 2

KMO AND BARTLETT'S TEST: FirST LEVEL FACTORISATION

\begin{tabular}{lrr}
\hline \multicolumn{2}{c}{ KMO and Bartlett's Test } \\
\hline KMO Measure of Sample Adequacy & & 0,976 \\
Bartlett's Test of Sphericity & Approx. Chi-Square & 100624,4 \\
& df & 820 \\
& Sig. & 0,000 \\
\hline
\end{tabular}

The eigenvalues of the unreduced item inter-correlation matrix were then calculated and are depicted in Table 3.

TABLE 3

EIGENVALUES OF THE UNREDUCED ITEM INTER-CORRELATION MATRIX

\begin{tabular}{|c|c|c|c|}
\hline \multicolumn{4}{|c|}{ Initial eigenvalues } \\
\hline Root & Eigenvalues & $\%$ of Variance & Cumulative \% \\
\hline 1 & 16,125 & 39,329 & 39,329 \\
\hline 2 & 2,145 & 5,232 & 44,561 \\
\hline 3 & 1,485 & 3,623 & 48,184 \\
\hline 4 & 1,162 & 2,809 & 50,993 \\
\hline 5 & 1,133 & 2,763 & 53,766 \\
\hline 6 & 0,994 & 2,425 & 56,181 \\
\hline 7 & 0,916 & 2,234 & 58,415 \\
\hline 8 & 0,902 & 2,199 & 60,613 \\
\hline 9 & 0,827 & 2,018 & 62,632 \\
\hline 10 & 0,819 & 1,997 & 64,829 \\
\hline 11 & 0,783 & 1,910 & 66,539 \\
\hline 12 & 0,706 & 1,723 & 68,262 \\
\hline 13 & 0,697 & 1,701 & 69,963 \\
\hline 14 & 0,667 & 1,626 & 71,591 \\
\hline 15 & 0,636 & 1,551 & 73,142 \\
\hline 16 & 0,627 & 1,529 & 74,671 \\
\hline 17 & 0,591 & 1,442 & 76,113 \\
\hline 18 & 0,585 & 1,428 & 77,541 \\
\hline 19 & 0,551 & 1,344 & 78,884 \\
\hline 20 & 0,549 & 1,340 & 80,225 \\
\hline 21 & 0,539 & 1,316 & 81,540 \\
\hline 22 & 0,487 & 1,189 & 82,729 \\
\hline 23 & 0,476 & 1,161 & 83,890 \\
\hline 24 & 0,461 & 1,125 & 85,015 \\
\hline 25 & 0,452 & 1,101 & 86,117 \\
\hline 26 & 0,447 & 1,091 & 87,208 \\
\hline 27 & 0,435 & 1,061 & 88,269 \\
\hline 28 & 0,417 & 1,016 & 89,285 \\
\hline 29 & 0,411 & 1,002 & 90,287 \\
\hline 30 & 0,402 & 0,980 & 91,267 \\
\hline 31 & 0,393 & 0,958 & 92,225 \\
\hline 32 & 0,378 & 0,922 & 93,147 \\
\hline 33 & 0,372 & 0,907 & 94,053 \\
\hline 34 & 0,363 & 0,885 & 94,938 \\
\hline 35 & 0,339 & 0,826 & 95,764 \\
\hline 36 & 0,337 & 0,821 & 96,585 \\
\hline 37 & 0,318 & 0,775 & 97,360 \\
\hline 38 & 0,304 & 0,742 & 98,102 \\
\hline 39 & 0,276 & 0,673 & 98,775 \\
\hline 40 & 0,265 & 0,646 & 99,421 \\
\hline 41 & 0,237 & 0,579 & 100,000 \\
\hline Trace & 41,00 & & \\
\hline
\end{tabular}

The next step was to postulate the number of factors. According to Kaiser's (1961) criterion (eigenvalues larger than unity), five factors were postulated as depicted in Table 3 .
TABLE 4

SORTED AND ROTATED FACTOR MATRIX OF THE FIRST LEVEL FACTOR ANALYSIS

\begin{tabular}{|c|c|c|c|c|c|}
\hline \multirow[b]{2}{*}{ ITEM } & \multicolumn{4}{|c|}{ FACTOR } & \multirow[b]{2}{*}{5} \\
\hline & 1 & 2 & 3 & 4 & \\
\hline 4 & 0,715 & & & & \\
\hline 30 & 0,663 & & & & \\
\hline 26 & 0,652 & & & & \\
\hline 29 & 0,646 & & & & \\
\hline 35 & 0,615 & 0,342 & & & \\
\hline 14 & 0,614 & & & & \\
\hline 10 & 0,602 & & & & \\
\hline 33 & 0,597 & & & & \\
\hline 36 & 0,695 & & & 0,310 & \\
\hline 16 & 0,688 & 0,335 & & & \\
\hline 25 & 0,640 & 0,360 & & & \\
\hline 31 & 0,639 & 0,404 & & & \\
\hline 7 & 0,481 & & 0,368 & & \\
\hline 13 & 0,465 & & 0,335 & 0,351 & \\
\hline 18 & 0,445 & & 0,359 & 0,323 & \\
\hline 6 & 0,443 & 0,414 & 0,338 & & \\
\hline 38 & 0,405 & & 0,367 & & \\
\hline 20 & 0,399 & 0,371 & & & \\
\hline 28 & 0,350 & & & & \\
\hline 3 & & 0,632 & & & \\
\hline 11 & 0,492 & 0,623 & & & \\
\hline 19 & 0,429 & 0,609 & & & \\
\hline 21 & 0,330 & 0,600 & & & \\
\hline 5 & & 0,552 & & & \\
\hline 41 & 0,488 & 0,495 & 0,354 & & \\
\hline 8 & 0,448 & 0,479 & & & \\
\hline 23 & & 0,352 & & & \\
\hline 4 & & 0,331 & & & \\
\hline 37 & 0,333 & & 0,646 & & \\
\hline 27 & 0,399 & & 0,522 & & \\
\hline 32 & 0,392 & 0,380 & 0,499 & & \\
\hline 24 & 0,384 & & 0,485 & & \\
\hline 1 & & & & 0,631 & \\
\hline 12 & & & & 0,511 & \\
\hline 34 & & & & 0,412 & \\
\hline 2 & & & & 0,399 & \\
\hline 39 & 0,307 & & & 0,358 & \\
\hline 40 & & & & 0,345 & \\
\hline 17 & & & & 0,288 & \\
\hline 15 & & & & 0,335 & 0,697 \\
\hline 22 & & & & & 0,607 \\
\hline
\end{tabular}

These five postulated factors explained $54 \%$ of the variance in the factor space. The sorted and rotated factor matrix appears in Table 4, indicating item-loadings on the five postulated factors. Sub-scores on these five factors were calculated and intercorrelated as shown in Table 5 .

TABLE 5

INTER-Correlation OF SUb-SCORES (SS)

\begin{tabular}{lccccc}
\hline & SS 1 & SS 2 & SS 3 & SS 4 & SS 5 \\
\hline Sub-score 1 & 1 & 0,812 & 0,783 & 0,564 & 0,381 \\
Sub-score 2 & 0,812 & 1 & 0,707 & 0,522 & 0,326 \\
Sub-score 3 & 0,783 & 0,707 & 1 & 0,471 & 0,329 \\
Sub-score 4 & 0,564 & 0,522 & 0,471 & 1 & 0,473 \\
Sub-score 5 & 0,381 & 0,326 & 0,329 & 0,473 & \\
\hline
\end{tabular}

All Correlations are significant at the 0,01 level (2-tailed) 
This inter-correlation matrix of sub-scores was also tested for its suitability for factor analysis. A KMO measure of sampling adequacy and Bartlett's Test for sphericity yielded acceptable results as can be inferred from Table 6 .

TABLE 6

KMO AND BARTLETT'S TEST: SECOND LEVEL FACTORISATION

\begin{tabular}{lrr}
\hline \multicolumn{2}{c}{ KMO and Bartlett's Test } \\
\hline Kaiser-Meyer-Olkin Measure of Sampling Adequacy & 0,813 \\
Bartlett's Test of Sphericity & Approx. Chi-Square & 12985,91 \\
& df & 10 \\
& Sig. & 0,000 \\
\hline
\end{tabular}

Eigenvalues were calculated on this inter-correlation matrix. Only one factor was postulated according to Kaiser's (1961) criterion. This factor explained $64 \%$ variance in the factor space as shown in Table 7.

TABLe 7

EIGENVALUES ON THE UNREDUCED INTER-CORRELATION MATRIX OF SUBSCORES

\begin{tabular}{lccc}
\hline Root & Eigenvalues & \% of Variance & Cumulative \% \\
\hline 1 & 3,202 & 64,048 & 64,048 \\
2 & 0,858 & 17,162 & 81,210 \\
3 & 0,483 & 9,662 & 90,871 \\
4 & 0,290 & 5,803 & 96,674 \\
5 & 0,166 & 3,326 & 100,0 \\
\hline
\end{tabular}

Trace $=5$

Table 8 depicts the loadings of subscores on the single postulated factor. All loadings were higher than 0,450 .

TABLE 8

SUB-SCORE LOADINGS ON POSTULATED SINGLE FACTOR

\begin{tabular}{lcc}
\hline Subscores & Factor $\mathbf{1}$ & $\mathbf{h}^{\mathbf{2}} \mathbf{j}$ \\
\hline 1 & 0,934 & 0,872 \\
2 & 0,847 & 0,717 \\
3 & 0,808 & 0,653 \\
4 & 0,639 & 0,408 \\
5 & 0,453 & 0,205 \\
\hline
\end{tabular}

In Table 9, the results of a reliability analysis are reflected in terms of item means, item variances, item-test correlations and item reliabilities. A coefficient of Alpha of 0,96 was obtained for the scale. This indicates that the Employment Equity Questionnaire is highly reliable to measure EE practices, thus satisfying the secondary objective of the study.
TABLE 9

Reliability analysis on Employment Equity Questionnaire

\begin{tabular}{|c|c|c|c|c|}
\hline Item & Scale Mean & Scale Variance & $\begin{array}{l}\text { Corrected Item } \\
\text { Total Correlation }\end{array}$ & $\begin{array}{c}\text { Alpha of } \\
\text { Item Deleted }\end{array}$ \\
\hline Q6 & 110,6900 & 389,2829 & 0,4414 & 0,9591 \\
\hline Q84 & 110,4181 & 393,0069 & 0,3233 & 9,9597 \\
\hline Q12 & 110,4379 & 383,1696 & 0,6517 & 0,9580 \\
\hline Q11 & 110,4726 & 387,7620 & 0,5353 & 0,9586 \\
\hline Q4 & 110,2068 & 383,7499 & 0,6274 & 0,9581 \\
\hline Q1 & 110,4441 & 380,5236 & 0,6648 & 0,9579 \\
\hline Q7 & 110,7951 & 379,4629 & 0,6817 & 0,9578 \\
\hline Q8 & 110,6786 & 382,7871 & 0,6068 & 0,9582 \\
\hline Q10 & 110,7568 & 378,8258 & 0,7497 & 0,9574 \\
\hline Q14 & 110,4944 & 380,7458 & 0,7164 & 0,9576 \\
\hline Q15 & 110,0340 & 380,5041 & 0,6419 & 0,9580 \\
\hline Q16 & 110,3698 & 392,2581 & 0,4280 & 0,9591 \\
\hline Q17 & 110,7720 & 379,8660 & 0,6734 & 0,9578 \\
\hline Q19 & 110,7111 & 379,4648 & 0,7136 & 0,9576 \\
\hline Q20 & 110,0406 & 394,9345 & 0,2957 & 0,9597 \\
\hline Q26 & 110,6481 & 380,0788 & 0,7050 & 0,9577 \\
\hline Q27 & 110,2502 & 394,1369 & 0,3177 & 0,9597 \\
\hline Q30 & 110,4836 & 383,3318 & 0,6800 & 0,9579 \\
\hline Q32 & 1105094 & 384,9957 & 0,6369 & 0,9581 \\
\hline Q34 & 110,4864 & 384,4673 & 0,6642 & 0,9580 \\
\hline Q37 & 110,4699 & 384,0351 & 0,6298 & 0,9581 \\
\hline Q38 & 110,5227 & 392,7690 & 0,3399 & 0,9596 \\
\hline Q76 & 110,5991 & 384,5638 & 0,5970 & 0,9583 \\
\hline Q41 & 110,3075 & 390,5319 & 0,4584 & 0,9590 \\
\hline Q45 & 110,6572 & 381,4296 & 0,6961 & 0,9577 \\
\hline Q46 & 110,6164 & 380,9882 & 0,7331 & 0,9576 \\
\hline Q94 & 110,5331 & 388,8289 & 0,5050 & 0,9587 \\
\hline Q48 & 110,5931 & 383,3632 & 0,6533 & 0,9580 \\
\hline Q54 & 110,7583 & 379,1194 & 0,7121 & 0,9576 \\
\hline Q55 & 110,6669 & 379,9185 & 0,7328 & 0,9575 \\
\hline Q56 & 110,5342 & 382,0708 & 0,6857 & 0,9578 \\
\hline Q57 & 110,5580 & 389,1845 & 0,4773 & 0,9589 \\
\hline Q58 & 110,7585 & 379,9451 & 0,7101 & 0,9576 \\
\hline Q59 & 110,2692 & 392,0889 & 0,4150 & 0,9592 \\
\hline Q60 & 110,5743 & 380,0347 & 0,7158 & 0,9576 \\
\hline Q63 & 110,6746 & 380,9480 & 0,7117 & 0,9577 \\
\hline Q65 & 110,0459 & 385,7938 & 0,5097 & 0,9588 \\
\hline Q71 & 110,4974 & 381,7204 & 0,6684 & 0,9579 \\
\hline Q81 & 110,3605 & 393,7319 & 0,3895 & 0,9592 \\
\hline Q82 & 110,3866 & 393,2600 & 0,3951 & 0,9592 \\
\hline Q9 & 110,6976 & 383,7766 & 0,6120 & 0,9592 \\
\hline
\end{tabular}

Alpha $=0,96$

On face value, the Employment Equity Questionnaire showed validity. By examining the items closer, however, despite the alpha coefficient of 0,96 , it was found that some of the 41 items were not clear in their focus or addressed multiple issues. This aspect will be discussed in more detail under 'discussion'.

Second phase of the data analyses

The main objective of the study was to determine whether there were response differences between the various age categories with respect to employment equity practices.

The mean employment equity scores for different age categories are presented in Table 10. From this Table, it is clear that there are observable differences in mean employment equity scores. 
The equality of error variances for the different mean scores was calculated with a Levene's Test (see Table 11). The results indicate that the error variances are not equal and that the Dunnett post hoc tests should therefore be interpreted.

TABLE 10

MEAN EMPLOYMENT EQUITY SCORES PER AGE CATEGORY

\begin{tabular}{lccc}
\hline Age Category & Mean & Standard Deviation & N \\
\hline 24 years and younger & 2,9302 & 0,38142 & 665 \\
$25-30$ years & 2,8912 & 0,38360 & 899 \\
$31-35$ years & 2,8629 & 0,40559 & 649 \\
$36-40$ years & 2,7623 & 0,50052 & 680 \\
$41-45$ years & 2,6653 & 0,50469 & 724 \\
$46-50$ years & 2,7497 & 0,49638 & 514 \\
51 years and older & 2,8687 & 0,44360 & 544 \\
Total & 2,8195 & 0,45343 & 4675 \\
\hline
\end{tabular}

TABLE 11

LEVENE'S TEST OF EQUALITY OF ERROR VARIANCE

\begin{tabular}{cccc}
\hline F & df1 & df2 & Sig. \\
\hline 20,684 & 6 & 4668 & 0,000
\end{tabular}

Tests the null hypothesis that the error variance of the dependent variable is equal across groups.

An ANOVA was conducted to test for the significance of different mean scores in different age categories. The results of the ANOVA indicate that significant differences were found between mean employment equity scores for different age groups (see Table 12). In order to eliminate the effect of unequal or large sample sizes the range was squared which yielded a Partial Eta squared of 0,04. This indicates that only $4 \%$ of the variance in response differences could be ascribed to differences in employment equity practices. This is of low practical significance.

TABLE 12

ANOVA - COMPARISON OF EMPLOYMENT EQUITY SCORES FOR AGE CATEGORIES

\begin{tabular}{lccccc}
\hline Source & $\begin{array}{c}\text { Type 111 Sum } \\
\text { of Squares }\end{array}$ & df & Mean Squares & F-Ratio & P(f) \\
\hline Corrected Model & 38,111 & 6 & 6,352 & 32,129 & 0,000 \\
Intercept & 36033,259 & 1 & 36033,259 & 182266,1 & 0,000 \\
AGE & 38,111 & 6 & 6,352 & 32,129 & 0,000 \\
Error & 922,844 & 4668 & 0,198 & & \\
Total & 38123,990 & 4675 & & & \\
Corrected Total & 960,955 & 4674 & & & \\
\hline
\end{tabular}

R Squared $=0,04$ (Adjusted R Squared $=0,038$ )

To determine how each age category differed in response as compared to the rest of the age categories, multiple post hoc comparisons were conducted, using the Dunnett post hoc test. Significant differences in scores between different age categories are evident from Table 13

The following section provides a discussion of these findings.
TABLE 13

DUnNetT T3 Post Hoc TeST - DEPENDENT VARIABLE: FACTOR 1

\begin{tabular}{|c|c|c|c|c|}
\hline (I) Age & (J) Age & $\begin{array}{c}\text { Mean } \\
\text { difference }\end{array}$ & Standard & Significance \\
\hline \multirow{6}{*}{24 years and younger } & 25-30 years & 0,0389 & 0,01956 & 0,633 \\
\hline & 31-35 years & 0,0673 * & 0,02173 & 0,041 \\
\hline & $36-40$ years & 0,1779 * & 0,02423 & 0,000 \\
\hline & 41-45 years & $0,2649^{*}$ & 0,02389 & 0,000 \\
\hline & 46-50 years & $0,1806^{*}$ & 0,02642 & 0,000 \\
\hline & $\begin{array}{l}51 \text { years and } \\
\text { older }\end{array}$ & 0,0614 & 0,02409 & 0,208 \\
\hline \multirow[t]{6}{*}{25 - 30 years } & $\begin{array}{l}24 \text { years and } \\
\text { younger }\end{array}$ & $-0,0389$ & 0,01956 & 0,633 \\
\hline & 31-35 years & 0,0283 & 0,02042 & 0,977 \\
\hline & $36-40$ years & 0,1390 * & 0,02307 & 0,000 \\
\hline & 41-45 years & 0,2260 * & 0,02270 & 0,000 \\
\hline & $46-50$ years & $0,1416^{*}$ & 0,02536 & 0,000 \\
\hline & $\begin{array}{l}51 \text { years and } \\
\text { older }\end{array}$ & 0,0225 & 0,02292 & 1,000 \\
\hline \multirow[t]{6}{*}{31 - 35 years } & $\begin{array}{l}24 \text { years and } \\
\text { younger }\end{array}$ & $-0,0673 *$ & 0,02173 & 0,041 \\
\hline & 25-30 years & $-0,0283$ & 0,02042 & 0,977 \\
\hline & $36-40$ years & $0,1106^{*}$ & 0,02494 & 0,000 \\
\hline & 41-45 years & $0,1976^{*}$ & 0,02460 & 0,000 \\
\hline & 46-50 years & 0,1132 * & 0,02707 & 0,001 \\
\hline & $\begin{array}{l}51 \text { years and } \\
\text { older }\end{array}$ & $-0,0058$ & 0,02480 & 1,000 \\
\hline \multirow[t]{6}{*}{$36-40$ years } & $\begin{array}{l}24 \text { years and } \\
\text { younger }\end{array}$ & $-0,1779 *$ & 0,02423 & 0,000 \\
\hline & 25-30 years & $-0,1390 *$ & 0,02307 & 0,000 \\
\hline & 31-35 years & $-0,1106^{*}$ & 0,02494 & 0,000 \\
\hline & 41-45 years & $0,0870^{*}$ & 0,02684 & 0,025 \\
\hline & $46-50$ years & 0,0260 & 0,02912 & 1,000 \\
\hline & $\begin{array}{l}51 \text { years and } \\
\text { older }\end{array}$ & $-0,1165^{*}$ & 0,02702 & 0,000 \\
\hline \multirow[t]{6}{*}{$41-45$ years } & $\begin{array}{l}24 \text { years and } \\
\text { younger }\end{array}$ & $-0,6490 *$ & 0,02389 & 0,000 \\
\hline & $25-30$ years & $-0,2260^{*}$ & 0,02270 & 0,000 \\
\hline & 31-35 years & $-0,1976^{*}$ & 0,02460 & 0,000 \\
\hline & $36-40$ years & $-0,0870^{*}$ & 0,02684 & 0,025 \\
\hline & $46-50$ years & $-0,0844$ & 0,02883 & 0,071 \\
\hline & $\begin{array}{l}51 \text { years and } \\
\text { older }\end{array}$ & $-0,2035^{*}$ & 0,02671 & 0,000 \\
\hline \multirow[t]{6}{*}{46 - 50 years } & $\begin{array}{l}24 \text { years and } \\
\text { younger }\end{array}$ & $-0,1805^{*}$ & 0,02642 & 0,000 \\
\hline & $25-30$ years & $-0,1416^{*}$ & 0,02536 & 0,000 \\
\hline & 31-35 years & $-0,1132 *$ & 0,02707 & 0,001 \\
\hline & $36-40$ years & $-0,0026$ & 0,02912 & 1,000 \\
\hline & 41 - 45 years & 0,0844 & 0,02883 & 0,071 \\
\hline & 51 years and $o$ & ler- 0,1191 * & 0,02900 & 0,001 \\
\hline \multirow[t]{6}{*}{51 years and older } & \multicolumn{2}{|c|}{24 years and younger- 0,0614} & 0,02409 & 0,206 \\
\hline & 25-30 years & $-0,0225$ & 0,02292 & 1,000 \\
\hline & 31-35 years & 0,0058 & 0,02480 & 1,000 \\
\hline & $36-40$ years & $0,1165^{*}$ & 0,02702 & 0,000 \\
\hline & $41-45$ years & $0,2035^{*}$ & 0,02671 & 0,000 \\
\hline & 46-50 years & 0,1191 * & 0,02900 & 0,001 \\
\hline
\end{tabular}

*significant on $<0,05$ level 


\section{DISCUSSION}

The data were generated by a sample of convenience constituted from voluntary respondents working in different organisations. The findings of this study can therefore only be generalised to the respondents of participating companies of this study and not to any other company or industry outside the current sampling frame.

A reliability analysis was conducted on single scale obtained from the second level factor analysis by calculating item means, item variance, item-test correlations and item reliabilities. A coefficient Alpha of 0,96 was obtained for the scale. This provides evidence that the Employment Equity Questionnaire is highly reliable to measure EE Practices, thus satisfying the secondary objective of the study.

In terms of the primary objective of the study, to determine if differences in responses on employment equity practices between different age categories do exist, a series of statistical procedures were conducted. The test results of the ANOVA indicated that overall significant differences in the responses of the various age categories do exist, but that only $4 \%$ of the variance in mean difference scores could be attributed to differences in employment equity practices. This small portion of variance is practically insignificant. The discriminant validity of the questionnaire (consisting of only 41 items of a pool of 146 items) in this respect can thus be questioned.

The following differences between age groups were identified by using post hoc contrast tests: It was found that the 24 years and younger category is more positive towards employment equity practices than the age groups between 31-50 years, excluding the group older than 51 years where there is no significant difference with the contrast group. The four age groups between 31 and 50 years were more negatively inclined. This could possibly be ascribed to young and energetic entrants into the labour market. The era of employment equity also brought with it more opportunities and career options to choose from. The global nature of job opportunities is also attractive to career entrants who are still mobile and mostly without family ties. This finding ties in with Schein's (1978) view on the early career stage and the accompanying developmental tasks of career establishment and achievement (Schreuder \& Theron, 2001).

Likewise the 25-30 years category feels significantly more positive on employment equity practices than the three 36 50 year groups, excluding the group older than 51 years where there is again no significant difference. These three mentioned groups responded more negatively on employment equity practices.

The group of 31-35 years responded significantly more positive on employment equity than the three groups between 36-50 years, excluding the group older than 51 years where there was no difference. The three mentioned groups responded more negatively on employment equity practices. This could possibly be ascribed to the fact that people want to settle down in careers after the age of 35 years, people start getting married and want to have children. The negativity of this group can be explained from the perspective of the mid-career stage, where people are often also facing the mid-life crisis and other existence related issues (Schreuder \& Theron, 2001). EE practices are therefore perceived as extremely negative and as thwarting career expectations. The differences in responses could also be as a result that competition for jobs are fiercer as more racial groups "contend" for positions and promotions. This is also the age when people start moving into higher income brackets and people not in favour of employment equity could perceive this as a threat. They could feel that the same equal opportunities are not available to "their children" or to themselves. This negative attitude could also be ascribed to the fact that these employees feel exploited and resisting the change. Typically one would expect people in this category to coach and mentor young employees. The negativity could be a result of an unwillingness to share their experiences and transfer of knowledge. The negativity could also be as a result of the blatant or subtle discrimination as stated by Goldberg (2000) where older employees often feel disillusioned if they are discriminated against.

The age group between 36-40 years responded significantly more positive than the category between $41-45$ years and more negatively than the one category older than 51 years and the three categories younger than 35 years. This could be due to the fact that for the 41-45 year group, it is easier to identify with the older categories. Suddenly, talks of "early retirement" are not so far-fetched anymore. Employees in this category also see themselves as "being there" very soon. Typically people in this category could "look down upon" the younger generation. Those who are more negative about employment equity, could see the youngsters "getting the opportunities we never had". Because the younger generation is perceived to have more energy and ambition, they could also be perceived as a threat. This group may also feel that they are being pushed out.

Overall, it appears as if the younger groups $(<35)$ feel progressively more positive about employment equity practices than the older group (35-50), excluding the age group older than 51 years who feels more positive again about employment equity.

The 51 and older category shows a significantly positive attitude. It might be that they do not feel threatened by younger employees anymore. It could also be that they know that statutory they have to retire and their focus lies there. Also at this age, traditionally, people have made their mark in life and become less ambitious or adopt a more balanced life style (Schreuder \& Theron, 2001). Another assumption could be that as McGregor (2000) stated, that the people are not aware that they are not aware that they are discriminated against, thus leaving high incidents of discrimination under-reported.

This study did not focus on exactly which areas of Human's (2000) conceptual model the differences in responses lie. Assuming that the population growth predictions (Figure 1) are correct, South Africa is soon going to find itself in deep trouble with regards to availability of skilled labour in the younger age categories. Apart from possible skills-exits to other countries, the impact of HIV/AIDS might contribute to this.

In relation to the Human (2000) model (Figure 2), companies will have to change their policies and procedures to accommodate older employees. They should work with government to also revisit the concept of statutory retirement age of 65 years for men and 60 years for women. This is consistent with findings of Goldberg (2000) who stated that shortages will exist in employment of older age categories. According to the predictions, the younger categories are going to become less, thus forcing older categories to stay in employment longer. As it is happening currently in the world arena, it might also be worthwhile to consider forging a proactive partnership with Government to formulate legislation to ensure that existing legislation against age discrimination is enforced, as was the case with the Age Discrimination Act of 1067 (29 U.S.C. 621 et seq.) in the United States, and The Human Rights Act 1998 (Commencement No. 2) Order 2000.

\section{Implications for managers}

From a Management of Diversity perspective, people have to be trained and consulted, and employment equity strategies should be communicated effectively. Companies will also have to revisit their benefit structures. As Stated by Thomas (1992) Affirmative Action initiatives can be deployed to address people's needs in a holistic manner. People's needs, like medical cover, pension benefits, etc., change, as they grow 
older and should be addressed. Companies could therefore consider more flexible work practices on how conditions of employment are applied. Virtual offices might be considered as this will ensure older people can work from home and do not have to face fears of accidents, of being mugged, or of extensive travelling.

As per the Human (2000) model, companies also need to ensure that EE is addressed in a systematic fashion and that results are measured in a performance management format. Many older people can still feel they "have what it takes" to deliver outputs. Targets could also be considered for age distribution, as is the case with race and gender currently and trends in age patterns should be monitored. The aged might become a scarce resource.

Organisations should also take into consideration the career stage of those people affected by EE practices. Companies should not shy away from their post-employment responsibilities in terms of further training and development, entrepreneurship opportunities or even job creation.

Companies can also invest in the younger age categories to "keep them alive". The drastic drop in younger categories as predicted in Figure 1 could be as a result of HIV/AIDS and preventative initiatives should be run in conjunction with schools and tertiary institutions. Time and money should also be invested in training and education of AIDS counselors and peer educators to "educate" the younger generations.

Inside these companies, the Human Resources departments need to play a more prominent role in managing diversity programs, the setting of creative policies and procedures. They should also run initiatives of change management, especially to change perceptions of older people. The roles of older employees can also change to a more coaching/mentoring role. This will become their job to train younger employees and to transfer years of experience and knowledge.

In closure, even though South Africa is tailing the western world in employment equity practices, $\mathrm{SA}$ is flowing down that same stream, and will be facing the same challenges. Why not learn from others' mistakes so that SA can go through the learning curve quicker? Politicians and policy makers need to change their mind-sets by revisiting the constitution and other relevant legislation and start to take charge of age related issues in employment equity.

\section{Recommendations for future research}

The questionnaire (the 41 items used in this research) itself can be reviewed to make it even more valid and reliable. The grouping of the questions can also be considered to more clearly address the domains of the conceptual model used. An area where the instrument can be improved is the composition of the items used. Some of the items were described vaguely, for example, question 26 states that "the company cares for it's employees" and question 41 states that "My co-workers and I talk openly with one another". It was not quite clear how these questions relate to employment equity. Talking openly does not indicate that the company is actually practicing sound employment equity.

It was also found that some of the questions were "double barrelled". Question 6 for example, states that: "I think all our employees display a good image in their contact with the public, their relationship with their colleagues and their general behaviour at work." This question could measure three different items, i.e. good image with customers, employees' relationships with colleagues, and, employees' behaviour at work. Another example is found in question 45 where it states that "I am happy with the amount of time, money and energy the company is spending on employee development". Once again, if the rater crossed a score 4 , does this mean that he/she agrees with the amount of money spent on every employee, the amount of time spent, or the amount of energy spent. The question would automatically arise: How does one measure the amount of energy spent?

Instead of leaving an item open to interpretation, it can be constructed in such a way that every item only measures one aspect of employment equity. Addressing these aspects may improve the discriminant validity of the questionnaire. It must however be noted that these recommendations only focus on the 41 items used for this study and cannot be generalized to the remaining 105 items of the questionnaire.

In future, companies also have to determine which aspects of employment equity contribute to most significant differences and focus their strategies on those areas.

As can be seen from the findings in this article, companies will have to be more creative on how they contract and apply conditions of employment to older employees. A study can be conducted on what benefits should be reviewed and how. Policies and procedures could also be addressed as part of this research. The actual impact of HIV/AIDS on younger age categories can be researched and how the impact of the pandemic can be countered with more effective Human Resource strategies.

\section{ACKNOWLEDGEMENT}

The authors are indebted to Prof Nico Martins of Organisational Diagnostics for providing the data set for conducting this research. The 41-item EEQ used in this research was abstracted from a larger item pool collected across various organisations and does not constitute the original Employment Equity Audit of Prof Martins. Data collected from each organisation by means of the Survey was supplemented by qualitive methods.

The authors would like to thank Riëtte Eiselen and her staff from Statcon at RAU for their professional service and valuable contribution regarding the data analysis for this project.

\section{REFERENCES}

Deloitte \& Touche (2001). Employment Equity, FSA Surveys. Department of Labour (2000). Employment Equity Report, Director of the Department of Labour, submitted to National Government.

Gerdes, L.C., Moore, C., Ochse, R. \& Van Ede, D. (1988). The Developing Adult. Durban: Butterworths.

Goldberg, B. (2002). Age Works: What corporate America must do to survive the Ageing of the workforce, New York: The Free Press.

Human, L., Bluen, S. \& Davies, R. (1999). Baking a new cake -How to Succeed at Employment Equity, Johannesburg: Knowledge Resources.

Human, L. (2000), A conceptual framework for an integrated EE/HR/SKILLS Strategy. Presentation made to The De Beers HR Stratman in June 2002. human@mweb.co.za.

Human, L. (2001). Cost or catalyst? Some comments on the business case and conditions for effective Employment Equity. South African Mercantile Law Journal, pp. 1-33.

Human, L. (2002). A Conceptual Framework for an Integrated EE/HR/Skills Strategy.

Leedy, P. D. (1996). Practical Research, New York: Macmillan Publishing Company.

Loden, M. (1996). Implementing Diversity, Boston: McGraw-Hill, Boston.

Martins, N. (1999). Questionnaire on Employment Equity. In association with Ernest \& Young. Unpublished document. 
McEvoy, G. M. \& Cascio, W. F. (1989). Cumulative Evidence of the relationship between Employee Age and Job Performance, Journal of Applied Psychology. February, 1989

McGregor, J., (2000). Discrimination against Older Workers significant and under-reported, New Zealand, Massey News Publications.

Noe, R. A. \& Hollenbeck, J. R. (2000). Human Resource Management, Boston: McGraw-Hill.

Organisational Diagnostics (1999). Employment Equity Questionnaire. Unpublished Document.

Policy Statement (2002). Help the Aged. A London based organisation. jenny.havis@helptheaged.org.uk.

Republic of South Africa (1997) The Basic Conditions of Employment Act, Act 75 of 1997, Government Gazette No. 18491, 5 December 1997.

Republic of South Africa (1998) The Employment Equity Act, Act 55 of 1998, Government Gazette No. 19370, 19 October 1998.

Republic of South Africa (1998), The Skills Development Act, Act 97 of 1998, Government Gazette No 19420, 2 November 1998.

Republic of South Africa (1999),The Constitution of South Africa, Act 108 of 1996, Government Gazette No. 19862, 19 March 1999.

Republic of South Africa (2002), The Labour Relations Act as Amended, Act 66 of 1995, Government Gazette No. 23540, 24 June 2002
Robbins, S. P. (2001). Organisational Behaviour, New Jersey: Prentice-Hall.

Schein, E. (1978). Career Dynamics: Matching Individual and Organisational Needs. Reading, MA.: Addison Wesley.

Schreuder, A.M.G. \& Theron, A.L. (2001). Careers: An Organisational Perspective. Landsdowne: Juta.

The Policy Book (2002). The American Association for Retired Persons.

The British Government, The Human Rights Act of 1998, Commencement No 2, Order October, 2000

The United States Code, The Age Discrimination in Employment Act, Act of 1967, Pub. L.90 - 202.

Thomas, W. (1992). Affirmative Action as a development tool in the SA business interface, Cape Town Chamber of Commerce, August, 12.

Thomas, A. \& Robertshaw, D. (1999). Achieving Employment Equity, Johannesburg: Knowledge Resources.

US Census Bureau (2002). http://www.census.gov

Republic of South Africa (1994). White paper on reconstruction and development. Notice no. 1954 of 1994, Government Gazette no. 16085, 15 November 1994.

Woolnough R. (2000). Age-Old Problem, Computer Weekly, March 16 